\title{
SANKSI TEGAS SERTA UPAYA HUKUM GUNA MENCEGAH TERJADINYA MONEY POLITIC PEMILU LEGISLATIF
}

\author{
Dairani \\ Prodi Hukum, Fakultas Ilmu Sosial dan Humaniora, \\ Universitas Ibrahimy, Situbondo Jawa Timur \\ Email: dayraas16@gmail.com
}

\begin{abstract}
Abstraks
Pemilu merupakan bagian dari negara yang menganut sistem demokrasi dalam menjalankan kegiatan pemerintahan. Pemilu juga merupakan cara memilih dan menentukan kepala negara yang juga kepala pemerintahan. Pasal 22E (2) UUD 1945 sebagai dasar hukum utama penyelenggaraan pemilu. Diselenggarakannya pemilu untuk menghasilkan anggota (DPR), (DPD) dan (DPRD). Pelaksanaan pemilu yang bersih, terbuka dan adil merupakan amanah tegas konstitusi untuk menciptakan pemilu yang demokratis dan berkualitas. Namun, pelanggaran, kecurangan, dan penyalahgunaan kekuasaan masih saja terjadi dalam praktik pemilihan umum. Politik uang merupakan salah satu isu hukum yang kuat hingga saat ini dan jumlahnya terus bertambah dari tahun sebelumnya dalam pemilihan umum, pemilihan kepala daerah dan pilkades. Politik uang merupakan usaha untuk membuat orang lain (masyarakat) empati dengan menggunakan materi sebagai imbalan dalam transaksi perdagangan suara sebelum dan selama pemilu. Dalam artikel ini, membahas tentang pengenaan sanksi hukum sebagai upaya hukum untuk mencegah praktik politik uang yang terjadi ketika sebuah pesta demokrasi diselenggarakan.
\end{abstract}

Kata Kunci : Sanksi, Upaya Hukum, Politik Uang, Pemilu.

\begin{abstract}
Elections are part of a country that adheres to a democratic system in carrying out government activities. Elections are also a way of selecting and determining the head of state who is also the head of government. Article 22E (2) of the 1945 Constitution as the main legal basis for holding elections. The holding of elections to produce members (DPR), (DPD) and (DPRD). The implementation of clean, open and fair elections is a firm mandate from the constitution to create quality and democratic elections. However, violations, fraud, and abuse of power still occur in
\end{abstract}


the practice of general elections. Money politics is one of the strong legal issues to date and the number continues to grow from the previous year in general elections, regional head elections and village head elections. Money politics is an attempt to make other people (society) empathize by using material as a reward in vote trading transactions before and during elections. In this article, we discuss the imposition of legal sanctions as a legal effort to prevent the practice of money politics that occurs when a democratic party is held.

Keywords : Sanctions, Legal Efforts, Money politic, Election.

\section{PENDAHULUAN}

\section{A. Latar Belakang}

Secara global, Indonesia satu dari banyak negara yang menganut demokrasi dalam praktik pemerintahannya. Sederhana demokrasi adalah kebebasan, kebebasan untuk berpendapat, memilih dan dipilih untuk apa saja yang dianggap baik dan tidak berlawanan dengan prinsip demokrasi yang dijalankan di Indonesia, karena Indonesia adalah negara dengan paham sistem demokrasi terbatas, dalam arti tidak bebas. Pancasila dijadikan sebagai tolak ukur dalam praktik penyelenggaraan pemerintahan karena Pancasila bukan hanya ideologi bangsa Indonesia, tetapi juga pondasi negara, dan sumber hukum negara. ${ }^{1}$

Demokrasi Indonesia adalah salah satu yang terbaik diantara banyak Negara demokrasi lainnya, bangsa Indonesia dalam pelaksanaan demokrasi menjunjung tinggi kerukunan, rasa hormat dan toleransi antar sesama bangsa Indonesia. Menjunjung tinggi toleransi dan saling menghormati merupakan sikap yang baik dan mendukung keberadaan hak asasi manusia yang termaktub dalam ketentuan UUD 1945 maupun dalam UU NO. 39 Tahun 1999 tentang HAM. ${ }^{2}$ Kembali ke konsep demokrasi, telah uraikan di atas demokrasi bermakna kebebasan yang dihadiahkan oleh pemerintah kepada rakyat untuk memilih pemimpin cakap dan mampu menyelesaikan tugas kepemimpinannya. Diantara wujud nyata kebebasan yang hadiahkan oleh negara kepada rakyat termasuk dalam proses pemilu, baik dalam pemilihan Presiden dan Wakil Presiden, pemilu Legislatif, serta pilkada dalam 5

1 Tim Kerja sosialisasi MPR Periode 2009-2014.Empat Pilar Kehidupan Berbangsa Dan Bernegara, seketariat jendral MPR RI, cetakan kedua November, 2012 h. 27

2 UU No. 39/1999 Tentang Hak Asasi Manusia

168 HUKMY|Jurnal Hukum 
(lima) tahun sekali dengan partisipasi langsung masyarakat dalam pemungutan suara sejalan dengan ketentuan yang tuliskan dalam UU No. 7/2017 tentang pemilu. ${ }^{3}$

Amandemen UUD ke-4 mengamanatkan penyelenggaraan pemilu secara langsung dengan berdasarkan bunyi Pasal 6A (1), (2) UUD 1945. Pemilu 2004 merupakan pemilu pertama yang diselenggarakan setelah perubahan UUD 1945. (SBY) wakilnya, Jusuf Kalla (JK) menang dalam pemilu tersebut, selanjutnya pemilu kembali diselenggarakan untuk memilih anggota legislatif dan dilanjutkan dengan pilkada, yang sebelumnya dipilih oleh DPRD berdasarkan UU No. 22/1999 tentang Pemda. ${ }^{4}$

Sejatinya Penyelenggaraan pemilu efektif dan bebas dari praktik-praktik yang merusak tatanan demokrasi, pemilu yang diselenggarakan dengan tidak adil tidak mencerminkan penyelenggaraan pemilu yang demokratis. UU No. 7/2017 tentang pemilu mengatur hal tersebut. Pasal 1 (1) penyelenggaraan pemilu harus dilakukan dengan mengutamakan prinsip luber-jurdil,5 serta berdasar pada nilai luhur Pancasila dan taat UUD $1945 .^{6}$

Telah diuraikan di atas bahwa, luber-jurdil merupakan asas dalam pemilu, gagasan dan program unggulan dijadikan hal penting dalam meraih kemenangan dan kekuasaan bukan hal lain apalagi uang. Sejalan dengan bunyi Pasal 93e UU No. 7 Tahun 2017 diantara tugas dari badan pengawas pemilu mencegah praktik Politik Uang. ${ }^{7}$ Realitanya, pelaksanaan pemilu dari satu masa ke masa tidak pernah terbebas Pratik money politics yang sejatinya hal tersebut tidak dapat dibenarkan. Namun demikian, praktik politik uang seolah-olah menjadi sesutu yang lumrah ketika seseorang berniat untuk maju sebagai calon legislatif hendaknya bersedia dana dalam jumlah yang banyak uang dianggap sebagai benda yang mampu menarik simpati masyarakat.

3 Sri Wahyu Ningsih, Tantangan Dalam Penanganan Dugaan Praktik Politik Uang Pada Pilkada Serentak 2017. Masalah - Masalah Hukum, Jilid 45 No. 1, Januari 2016. p-ISSN : 2086-2695, e-ISSN : $2527-$ 4716. h. 34

4 Yuli Santoso, Politik Uang Dalam Pemilihan Umum Legislatif. 2019. h, 4

5 UU No. $7 / 2017$ Tentang Pemilu Pasal 1 (1)

${ }^{6}$ Ibid,

${ }^{7}$ UU No. 7/2017 Tentang Pemilu Pasal 93 point e 
Berdasar pada regulasi yang ada, praktik di atas tidak dibenarkan, sebab dalam regulasi pemilu politik uang adalah perbuatan tercela dan tidak terpuji karena mengotori dan menodai marwah demokrasi, namun kenyataannya hal tersebut tetap terjadi dan seolah-olah modal yang manjur agar meraih empati pemilih. Namun yang perlu di pahami bersama adalah bahwa politik uang tidak begitu saja terjadi dengan tidak adanya pemberi dan penerima. Money politic adalah suatu metode peserta pemilu yang bertujuan untuk mendapat simpati pemilik hak pilih dengan imbalan atau janji-janji belaka. ${ }^{8}$

Terjadinya praktik di atas, buka semata-mata karena uang merupakan segalanya bagi masyarakat atau bagi calon sebaliknya, namun masyarakat melakukan hal tersebut karena faktor peserta pemilu yang melupakan simpatisan dan masyarakat yang menjadikannya sebagai anggota dewan, hal ini tidak hampir terjadi pada semua anggota legislatif baik di tingkat pusat dan daerah. ${ }^{9}$ Dalam penelitian sederhana yang dilakukan di masyarakat desa yang menjadi tujuan utama para pelaku politik uang, alasan kuat masyarakat mau menerima uang calon legislatif karena mereka yakin ketika nanti sudah dilantik ia akan dilupakan, sehingga mengambil uangnya diawal merupakkan metode yang digunakan masyarakat desa agar dapat menikmati hak-hak mereka yang akan terabaikan lima tahun kedepan. ${ }^{10}$ Mereka menyadari bahwa janji dan kampanye yang disampaikan dalam bentuk orasi hanya akal-akalan belaka agar masyarakat mau memilihnya. Jika ditelisik dan diperhatikan secara mendalam kepentingan golongan, kelompok, partai pengusung menjadi yang paling dipikirkan oleh legislatif. Misi balas dendam dan kesempatan selalu berjalan beriringan dengan tujuan para pelaku politik uang dalam pemilu legislatif.

Tuntutan keadaan serta situasi dan kondisi di lapangan adalah factor utama peserta pemilu berani mengeluarkan uang dengan jumlah yang tidak sedikit walaupun mereka kadang terpaksa melakukan itu, namun kondisi menghendaki demikian. Disamping kondisi dilapangan, ketidakpercayaan diri juga mendorong

\footnotetext{
8 Sri Wahyu Ningsih, Tantangan Dalam Penanganan Dugaan Praktik Politik Uang Pada Pilkada Serentak 2017. Masalah - Masalah Hukum, Jilid 45 No. 1, Januari 2016. p-ISSN : 2086-2695, e-ISSN : 2527 4716. h. 50

${ }^{9}$ Ibid, h. 26

10 Ibid,
}

\section{HUKMY|Jurnal Hukum}


seseorang untuk melakukan praktik politik uang guna menarik perhatian pemilih agar memilihnya sehingga ia akan berupaya mendapatkan uang mahar tersebut meski dengan cara menjual asset atau meminjam ke bank. Sehingga tidak jarang dijumpai peserta pemilu yang tidak terpilih menjadi stress dan gila karena memikirkan jumlah uang yang banyak yang dikeluarkan namun juga tidak membuatnya terpilih.

Praktik politik uang jika terus menerus terjadi dan tidak ditindak tegas maka jelas hal ini akan menjadi salah satu faktor rusaknya sistem demokrasi pemilu khususnya di Indonesia. tidak hanya demikian kedaulatan yang semula berada di tangan dan sebagai kedaulatan tertinggi dalam suatu negara akan berubah menjadi kedaulatan uang sebagai kekuasaan tertinggi. Sehingga diperlukan upaya-upaya hukum guna mencegah, mengurangi dan sekaligus menghapus praktik money politics di pelaksanaan pemilu agar tercapai pemilu yang berkualitas.

\section{B. Batasan Masalah}

Batasan masalah yang akan ditelaah dalam artikel ini adalah pengenaan sanksi yang berat terhadap pelaku politik uang terkait dengan upaya hukum guna meminimalisir politik uang dalam penyelenggaraan pemilu parlemen di Indonesia. Artikel ini bermaksud untuk menggali dan menganalisis sanksi yang dapat menghalangi pelaku, baik penerima maupun pemberi, dan kemudian untuk mengeksplorasi dan menganalisis upaya hukum yang relevan untuk mencegah kebijakan politik uang yang biasa terjadi selama pelaksanaan Pemilihan Umum sehingga pemilu yang akan datang dapat tercipta sesuai dengan prinsip pemilu dan mampu menghasilkan pemimpin yang berkualitas dan amanah.

\section{Motode Penelitian}

Studi hukum normatif digunakan dalam artikel ini sebagai pisau analisis dengan menggunakan pendekatan perundang-undangan yang berkaitan dengan objek yang menjadi fokus penelitian yaitu uu pemilu. Sebab, regulasi pemilu disamping aturan hukum lainnya misal KUHP, uu pemilu menjadi landasan utama dalam penerapan sanksi terhadap pelaku politik uang dalam pemilu legislatif. Pendekatan uu digunakan dengan tujuan guna mengetahui sejauh apa sanksi dalam 
ketentuan uu tersebut telah di implementasikan pada kasus-kasus yang terjadi sehingga dapat memberikan efek jera terhadap pelaku dan oknum lainnya yang berniat melakukan tindakan sepura (politik uang).

\section{PEMBAHASAN}

\section{Penerapan Sanksi bagi Pelaku Money Politics pemilu legislatif}

Pemilu legislatif yang secara bersamaan memilih DPR, DPD, dan DPRD di tingkat pusat, provinsi kab/kota merupakan proses agar mencapai legitimasi formal yang dilakukan dengan melibatkan calon dan pemilih yang dikendalikan oleh otoritas pengawas yang punya kewenangan. Bawaslu dan DKPP berwenang guna tegaknya etik jika terjadi terjadi pelanggaran etik oleh pelaksana pemilu, yang bertujuan agar hasil pemilu memiliki legalitas masyarakat yang disahkan berdasarkan undang-undang yang berlaku. Calon dengan perolehan suara terbanyak disebut pemenang pemilu dan berhak dilantik dalam majelis perwakilan rakyat untuk menjadi wakil daripada rakyat Indonesia. ${ }^{11}$

Pemilu di Indonesia mengalami beberapa kali perubahan dalam praktiknya. Pemiliu berlangsung untuk memilih Presiden, Wakil Presiden, legislatif dan kepala daerah yang dilaksanakan secara serentak sejak tahun 2015, 2017, 2018, 2019 dan 2020. Melalui pemungutan suara langsung, diharapkan dapat menemukan pimpinan atau wakil di parlemen yang sesuai dengan kehendak dan dapat mewakili aspirasinya. Tahapan pelaksanaan pemilu terdiri dari beberapa tahap, yaitu identifikasi daftar pemilih, pendaftaran dan identifikasi calon anggota legislatif, kampanye, sampai dengan masa diam, drop out, penghitungan suara, penghitungan suara, menentukan untuk memenangkan pemilihan dengan jumlah suara paling banyak selanjutnya dilantik sebagai anggota parlemen. ${ }^{12}$

Kampanye merupakan upaya menarik simpati pemilih secara persuasif (noncoercive) dengan retorika hubungan masyarakat, media informasi, lobi dan kegiatan lainnya. Kampanye berpengaruh besar pada hasil pemilu. Kampanye bermasuk untuk

\footnotetext{
11 Andi Akbar. Pengaruh Money Politics Terhadap Partisipasi Masyrakat Pada Pilkada 2015 Di Kabupaten Bulukumba, Program Studi Ilmu Politik Fakultas Ushuluddin, Filsafat Dan Ilmu Politik Universitas Islam Negeri (Uin) Alauddin Makassar. h. 2

12 Ibid, h.3
}

\section{HUKMY|Jurnal Hukum}


dapat dukungan dan persetujuan dari pemegang hak suara, kampanye sering kali dipimpin oleh orang yang berpengaruh untuk menjalankan strategi agar kampanye sukses. Untuk mencapai penghitungan suara, kampanye boleh melakukan apa saja dengan catatan masih berada pada batas sopan dalam berpolitik. ${ }^{13}$

Pelanggaran pemilu memang tidak dapat disangkal, terutama pada masa pemilu, diantaranya politik uang, kegiatan Politik uang terutama dilakukan oleh calon-calon potensial dan oleh tim sukses untuk mendapatkan suara dan pendukung untuk dipilih. calon tunggal yang memberikan kompensasi berupa uang atau materi berbeda. Selain itu, data tersebut berasal dari survei yang dilakukan oleh (LSN), pemilu 2014 dan 2019 potensi politik uang sangat besar. Umumnya masyarakat menyatakan bersedia mendapat hadiah uang tunai dari peserta legislatif atau parpol sebelum pemilu legislatif tanggal 9 April 2014 sejumlah 69,1\% menyatakan mau menerima hadiah tunai dari peserta dan parpol, meski alasan yang tidak sama. Selama pemilu tahun 2009, survei kebijakan moneter mengungkapkan bahwa kurang 40\% masyarakat mau mendapat hadiah uang dari kandidat atau parpol dalam pemilu legislatif, pada tahun 2019, angka ini sedikit menurun dibandingkan tahun 2014, yaitu 59,1\%. Masyarakat bersedia mendapat hadiah dari calon legislatif. ${ }^{14}$

Sebanyak 1.230 responden dari 34 Provinsi di Indonesia, cuma 30,9\% responden yang tegas menolak pemberian uang dari caleg atau parpol. Tingginya angka persentase responden yang mau menerima uang dari caleg atau dari partai merupakan sebuah indikator konkrit bahwa potensi money politics di pemilu tahun 2014 cukup tinggi. Terbukanya masyarakat untuk politik uang menjadi instrumen meluasnya terjadinya politik uang untuk mendapat suara banyak. Hasil survei oleh LSN menunjukkan secara umum masyrakat sudah sadar dan menerima money politics baik dari calon kandidat ataupun parpol, jumlah masyarakat yang berkenan menerima hadiah terus meningkat sejak pemilu tahun 2009, 2014 dan Tahun 2019.15

\footnotetext{
13 Roem Topatimasang, Menutup Pintu Masuk Politik Uang (Jakarta: Maarif Institute, 2011) h. 92

14 Apriliani Gita Fitria." Survei, Pemilu 2014 Lebih Rawan Politik Uang dalam pemilu", Temponews.com, 26032014 dan 2019 http://pemilu.tempo.co/read/news/269565384/p-SurveiiPemilu- 2014-Lebih-Rawan Politik-Uang dibanding 2019 ( 10 Oktober 2021)

15 Ibid,
} 
Politik uang memang susah didefiniskan, sebab setiap orang bisa mendefinisikan dari sudut yang berbeda-beda. Abdul Kholiq mengungkapkan kebijakan politik uang sebagai tindakan menyalurkan uang/hadiah atau dokumen yang lain, milik pribadi (calon legislatif/presiden,wakil presiden untuk mendulang suara tinggi dari adanya pemilu. politik uang adalah upaya untuk menekan orang lain dengan memberikan hadiah atau materi disaat pemilu untuk memperpanjang kekuasaan. Tambahkan M Abdul Kholiq mengemukakan bahwa kebijakan politik uang suatu penawaran dalam bentuk uang/bahan lain (sembako) atau membuat janji yang mencoba mempengaruhi manusia untuk mengadakan pemungutan suara supaya masyarakat tidak menggunakan hak pilihnya. hak untuk memilih atau orang yang menggunakan haknya dengan cara tertentu dalam pemilihan umum; ${ }^{16}$

Bentuk politik uang terjadi di Indonesia menurut Hamdan Zoelva yaitu:

1. Poltik Uang yang terjadi di kalangan masyarkat kelas atas atau pemilik modal besar. Dengan kesepakatan-kesepakatan jika nantinya terpilih mendapatkan kebijakan yang menguntungkan pemegang modal secara keseluruhan. Money politic ini memberikan pengaruh dan dampak yang luar biasa dalam praktik berpolitik. Sebab, pemegang modal besar dapat mengarahkan kebijakan parpol dan peserta guna menang dalam pemilu.

2. Politik uang pada masyarakat kelas menengah, terjadi antara elit politik dengan calon dan elit partai, dengan memberi uang kepada pribadi elit parpol guna mengatur letak nomor urut calon serta menentukan daerah pemilihan atau dapil.

3. Politik Uang terjadi pada masyarakat secara umum yaitu dari peserta pemilu dengan masyarakat pemilih. Hal ini dapat berupa uang tunai, makanan pokok, atau hal-hal lain yang dijanjikan yang dapat memberi pengaruh terhadap pola piker pemilih. ${ }^{17}$

Pandangan masyarakat awam memaknai politik uang sama halnya korupsi yang dalam KBBI Korupsi adalah memberi dan penerimaan hadiah dll. Kebijakan politik uang

16 M. Abdul Kholiq, 2014, "Perspektif Hukum Pidana tentang Fenomena Money Politics dan Korupsi Politk dalam Pemilu". Disampaikan pada Seminar Nasional Mewujudkan Pemilu yang Demokratis, Forum Kajian dan Penulisan Hukum (FKPH) Fakultas Hukum Universitas Islam Indonesia Yogjakarta Tanggal 22 Maret 2014.(15 Oktober 2021)

17 Hamdan Zoelva, 2014, Instrumen Hukum dan Penindakan Money Politic. http://s3.amazonaws.comacademia.edu.documents/34118878/CATATAN TERHADAP PENCEG AHAN_MONEY_POLITICS-libre.pdf?AWSAccessKeyId=AKIAJ56TQJRTWSMTNPEA\&Expires= 1413044544\&Signature $=u 1 d d S V D S F E y$ 7DZmSGRMfqHYGHI\%3D (diakses pada 12 Oktober 2021)

174 HUKMY|Jurnal Hukum 
memiliki arti yang sama ketika dengan korupsi manakala dilaksanakan untuk memfasilitasi dan memberikan pengaruh terhadap hasil pemilu dengan tindakan yang melanggar serta menghambat kebebasan HAM di mana setiap orang bebas secara demokratis untuk menentukan calon legislatif. Korupsi dan politik uang bisa terjadi oleh sebab adanya prosedur politik yang cacat. Namun, perilaku menyimpang itu juga telah menjadi ciri budaya di masyarakat, seperti gejolak dalam pemilihan anggota parlemen baru-baru ini dan dalam setiap peristiwa Pilkada.

Seorang calon tidak lagi malu memberikan uang agar memperoleh suara yang unggul pada proses pemilihan. Sebab, komunitas dan kelompok masyarakat tertentu telah memposisikan dirinya sebagai penonton yang nyaman serta siap memberikan layanan suara kepada kandidat yang membutuhkan. Dengan demikian, terjadilah transaksi politik yang korup antara pemberi dan penerima suap (korupsi dan suap).

Umumnya politik uang dipahami sebagai bentuk seni guna mendapatkan simpati dan suara yang tinggi serta memperoleh kekuasaan serta politik uang sebagai jembatan kokoh untuk meraih kekuasaan. Ismawan berpendapat politik uang juga dimaknai suatu upaya merubah perilaku orang dengan imbalan tertentu ketika proses pemilu berjalan dilapangan baik dari tingkat pusat hingga ke tatanan desa. ${ }^{18}$ Dalam perjalanannya, kebijakan politik uang merupakan proses mendistribusikan hadiah, barang dan jasa kepada pemilik hak suara. Ismawan kembali berpendapat bahwa, kebijakan politik uang disadari oleh setiap pelaku dan penerima. ${ }^{19}$

Dalam pengertian di atas, kebijakan mahar politik bisa dipahami sebagai bentuk pemberian dan penerimaan apapun untuk mempengaruhi pilihan pemimpin seseorang dalam pemilihan umum untuk agar meraih kekusaan. Komunikasi ilmu politik, pelaku kebijakan mahar politik pemilu legislatif dibedakan 3, yaitu calon, pendukung, dan pemilih. dua bentuk Tim sukses sebagai berikut:

1. Formal: Tim ini bekerja dengan professional dan terstruktur guna memberi dukungan ke kandidat. Tim ini memiliki sumber daya kuat baik massa dan sumber daya keuangan.

18 Muhammad Amanu. Politik Uang dalam Pemilihan Kepala Desa (Studi Kasus di Desa Jatirejo Kecamatan Banyakan Kabupaten Kediri) Jurnal Hukum Masyarakat Desa. Vol. 5. 2015. h, 8

19 Ibid, 
2. Nonformal: Dalam tim ini biasanya terbentuk secara otodidak yang keanggoataannya terdiri dari sahabat, teman, simpatisan serta keluarga yang mekanisme bekerjanya berbeda dengan tim formal di atas.

Hastuti mengungkapkan, penyebaran politik uang umumnya menggunakan dua cara yaitu :

1. Kampanye: yaitu sebuah mekanisme yang dipersiapkan secara sadar, bertahap serta berlanjut dalam waktu tertentu dengan maksud memperoleh simpati dari pemilik hak suara. Disinilah terkadang pemberian uang politik dilakukan oleh masing-masing kandidat.

2. Serangan subuh: hal ini dilakukan dengan datang ke satu persatu pintu pemilih untuk memberi uang dan foto kandidat yang akan dipilih.

Menurut Hastuti bentuk politik uang diberikan dengan tiga bentuk yaitu: ${ }^{20}$

1. Uang : langsung diberikan kepada pemilih dengan nominal yang berbeda dalam setiap pemilu dan pilkada.

2. Barang : barang dapat berbentuk sembako, baju, souvenir dan sejenisnya.

3. Kolektif untuk umum: hal ini dilakukan calon dengan memberikan perbaikan pada tempat ibadah atau saran umum dan di tambah dengan janji-janji politik setelah terpilih. ${ }^{21}$

Bentuk persoalan pertama dari kebijakan politik uang, yaitu bentuk komoditas, juga dibagi menjadi beberapa kategori antara lain uang, sembako dan souvenir. Masalah kedua, munculnya mahar poltik karena rekrutmen parpol tidak optimal untuk merekrut pengurus partai kader atau kandidat tersebut. Parpol kini cenderung memilih calon dengan uang lebih banyak daripada calon dengan ide atau program kerja yang bisa dipublikasikan untuk merebut simpati masyarakat atau pemilih. Ketiga, disebabkan adanya ketidakpercayaan pemilih kepada calon dalam pemilihan legislatif. Tidak bisa dipungkiri karena ketika terpilih, wakil rakyat melupakan dapil dan masyarakat. ${ }^{22}$

Oleh karena itu, peneliti berpandangan, lahir dan berkembangnya kebijakan politik uang dapat berpengaruh besar terhadap kelangsungan demokrasi, terutama dalam proses pemilu legislatif yang banyak terjadi pelanggaran pemilu. jika dibiarkan

\footnotetext{
20 Ibid,

${ }^{21}$ Ibid, $h 10$

22 Ibid,
}

176 HUKMY|Jurnal Hukum 
hal ini berdampak pada kedaulatan pemilih dan memilih calon. Pasal 1 (2) UUD 1945 kebebasan memilih dari hati nurani siapa yang disukai adalah hak rakyat, bukan pada jumlah uang yang didapat. Tingginya biaya dan ongkos pemilu yang harus ditanggung calon menjadi dampak kedua yang tidak bisa di hindari, maka sebagai akibat dari dua hal di atas potensi terjadinya penyelahgunaan kekuasaan hingga korupsi rentan terjadi.

Tidak ada alasan apapun yang dapat membenarkan adanya politik uang sehingga kebiasaan tersebut wajib dihilangkan dalam praktik demokrasi agar dapat sejalan dengan UU No. 7/2017 tentang pemilu. Pasal 426 (1) d secara tegas tentang sanksi berat bagi pelaku politik uang pemilu legislatif. Pasal 515 kembali menegaskan terkait ancaman pidana dan denda bagi para pelaku politik uang yang diancam pidana tiga tahun serta Rp. 36.000 .000 sebagai denda. ${ }^{23}$ Pasal 523(1),,24 memberi ancaman kepada kandidat yang dalam kampanye diketahui memberikan hadiah berupa uang dan sejenisnya diancam dengan pidana kurungan selama 2 tahun dan uang denda sejumlah Rp. 24.000.000,00.25

Bila diperhatikan dengan seksama, sebenarnya UU No. 7/2017 telah tegas mengatur berikut sanksi bagi pelanggar. Diantaranya adalah pembatalan kepesertaan calon anggota, batal demi hukum terhadap perolehan surat suara yang sebelumnya disinyalir terjadi pelanggaran serta sanksi penjara yang dapat diberikan kepada onkum atau pelanggar pemilu yakni politik uang. Bagusnya regulasi dan aturan tentang mekanisme hingga sanksi namun tidak ikuti dengan kesadaran dari penyelenggara, peserta dan pemilih, politik uang akan menempati panggung tinggi dalam pelanggaran pemilu, karenanya, kesadaran diri ketaatan terhadap regulasi meerupakan faktor penting serta utama guna meraih suksesnya demokrasi pemilu Presiden dan Wakil Presiden maupun dalam pemilu anggota parlemen.

\section{Hukum Sebagai Sarana Mencegah Politik Uang Pemilu Legislatif}

Pengetatan regulasi pemilu menjadi satu diantara upaya lainnya dalam mengatasi persoalan politik uang. Mencegah politik uang sebagai antisipasi supaya

\footnotetext{
23 Pasal 426 (1) d UU Pemilu

24 Pasal 523(1)

25 UU No. $7 / 2017$ tentang Pemilu
} 
praktik kotor tersebut dapat dihilangkan dalam pelaksanaan pemilu. Diperlukan langkah-langkah yang bersifat preventif semaksimal mungkin agar pemilu yang berkualitas dapat dicapai, sesuatu yang wajib diperhatikan adalah metode-metode hukum yang relevan diperlukan untuk meminimalisir serta menghambat laju Pratik kotor tersebut. Upaya-upaya yang wajib diperhatikan guna menghambat laju politik uang yaitu: Hukum sebagai sarana utama dalam upaya pencegahan, regulasi yang tepat serta tidak pandang bulu dalam praktiknya merupakan sarana utama dalam menghindari terjadinya praktik politik uang. Apalagi didukung dengan praktik yudikasi serta proses eksekusi hukuman dalam dunia peradilan mampu menjadi salah satu penghambat laju politik uang di era modern.

\section{a. Kebijakan Legislasi:}

Menggolongkan politik uang sebagai salah satu dari bentuk kejahatan yang dapat diancam dengan sanksi tegas dan berat dapat dipertimbangka sebab selama ini belum ada regulasi pemilu yang mengatur hal tersebut khususnya dalam penegakan hukum pidana menurut teori Von Feurbach, kejahatan kemudian diancam dengan sanksi berat bagi pelaku politik uang akan memberi pengaruh psikologi seseorang.

\section{b. Kebijakan Yudikasi:}

Kebijakan ini lebih melekat secara khusus kepada badan penyelenggara pemilu, KPU, Bawaslu dan DKPP. Kerjasama, profesionalitas, kemampuan SDM yang mempuni, serta integritas dari masing-masing lembaga tersebut di atas sangat diperlukan. Kasus-kasus yang tidak dapat tertangani dengan baik di lapangan salah satunya disebabkan karena tidak ada kerjsama dan profesionalisme yang baik dari lembagalembaga penyelenggara. Sehingga lembaga penyelenggara harus bersama-sama menegakkan hukum sesuai dengan aturan yang ada.

\section{c. Kebijakan Eksekusi:}

Memantapkan dan memberi hukuman yang maksimal terhadap pelanggar pemilu, serta meningkatkan fungsi pengawasan oleh lembaga berwajib sangat penting dilakukan. upaya ini bermaksud untuk memastikan putusan hakim agar sesuai dengan ketentuan yang ada. 26

26 Hamdan Zoelva, 2014, Instrumen Hukum dan Penindakan Money Politic. http://s3.amazonaws.comacademia.edu.documents/34118878/CATATAN TERHADAP PENCEG

178 HUKMY|Jurnal Hukum 
Ketiga upaya atau teori di atas jika benar pada pelaksanaannya akan mendatangkan rasa percaya diri dan hasil yang diharapkan bahwa praktik kotor uang politik dapat diberantas. Hingga pada akhirnya lambat laun pesan moral UUD 1945 Pasal 22E dapat dicapai dan dapat menghasilkan pimpinan yang berintegeritas tinggi serta punya berkualitas. Disisi lain, pemerintah menetapkan bahwa persoalan politik uang adalah sebuah persoalan serius yang harus segera dicari cara dan solusi guna meredem dan mengatasinya dalam semua praktik pemilu yang melibatkan masyarakat secara langsung di lapangan. Sehingga pada akhirnya kembali pada luber-jurdil. ${ }^{27}$

Disahkannya UU No 7/2017 yang mengatur pemilu secara subtansi dari UU tersebut telah banyak mengakomodir dan menetapkan tentang upaya dan sanksi tegas terhadap para oknum yang bermain politik uang. Upaya yang lain dari pemerintah melalui UU pemilu memberikan kewenangan ke bawaslu guna mengontrol penyelenggaraan pemilu mulai tahap awal hingga akhir, serta memberi ruang terbuka bagi masyarakat atau siapa saja yang merasa dirugikan atau ditemukan kecurangan dan ketidakjujuran dari peserta dan penyelenggara dapat diadukan ke bawaslu. Secara khsuus bawaslu juga diber kewenangan untuk persoalan politik uang Pasal 93e. ${ }^{28}$ Pasal 95c bawaslu berwenang melakukan pemeriksaan, pengkajian, serta memutuskan persoalan yang terjadi. Bawaslu Pusat diatur Pasal 93e, Provinsi Pasal 97c, Kab/ Kota Pasal 101c, Kecamatan Pasal 105c serta Panwaslu Kel/Desa Pasal 108b dan Panwaslu Luar Negeri Pasal 111b semua berwenang mengawasi serta mencegah politik Uang.

Kampanye merupakan tahapan dari penyelenggaraan pemilu pada kondisi ini kecurangan cendrung terjadi, baik dari penyelenggara, peserta, tim sukses serta parpol terkait atau pengusung. Mengantisipasi hal tersebut Pasal 280 secara jelas tidak memberikan ruang yang dapat merusak demokrasi dan hakikat kedaulatan rakyat diantaranya politik uang. Pasal 280 (1) j $\mathrm{j}^{29}$ menegaskan setiap penyelenggara, peserta dan tim pemenangan tidak dibenarkan memberi dan menjanjikan Sesuatu kepada

AHAN_MONEY_POLITICS-libre.pdf?AWSAccessKeyId=AKIAJ56TQJRTWSMTNPEA\&Expires= 1413044544\&Signature $=u 1 d$ dSVDSFEys7DZmSGRMfqHYGHI\%3D (diakses pada 12 Oktober 2021)

27 Dairani, D., 2021. Argumentasi Hukum Dan Upaya Mempertahankan Eksistensi Pancasila Sebagai Sumber Dari Segala Sumber Hukum Negara. HUKMY: Jurnal Hukum, 1(1), pp.19-34.

${ }^{28}$ Undang-undang Nomor 7 Tahun 2017 Tentang pemilu Pasal 93 huruf e.

${ }^{29}$ Pasal 280 (1) j UU Pemilu 
masyarakat. Pasal 280 (4) mengatur tentang pelanggaran Pasal 280 (1) huruf j mengklasifikasikan tindak pidana pemilu yang di atur Pasal 280 (1) pada point c, f, g, I, dan j, ayat (2) menjelaskan terkait tindak pidana Pemilu. ${ }^{30}$ Posisi politik uang di UU No. 7/2017 Tentang Pemilu diatur pada Pasal 286 (1) ${ }^{31}$ dengan tegas di jelaskan "setiap orang yang terlibat dalam pemilu kandidat, penyelenggara, tim dan masyarakat dilarang menjadikan politik uang sebagai bagian dari kampanye pemilu" Pasal $426(1)^{32}$ huruf $d$ terkait mekanisme pergantian peserta pemilu terpilih namun terbukti melakukan tindak pidana politik uang berdasarkan putusan tetap pengadilan. ${ }^{33}$

\section{KESIMPULAN}

Kesimpulan berdasarkan hasil penelitian artikel ini adalah sebagai berikut :

1. Politik uang sebagai satu diantara banyak pelanggaran yang terjadi dalam pemilu dapat menciderai marwa demokrasi pemilu legislatif dan pilkada secara umum. UU No. 7/2017 tegas dan jelas adanya larangan yang disertai dengan sanksi tegas bagi pelaku politik uang. Diantara terdapat sanksi administrasi berupa dibatalkannya calon yang terbukti melakukan politik uang, lalu dibatalkannya hasil perolehan suara bila sebelumnya terjadi dan terbukti adanya pelanggaran, hukuman pidana bagi calon anggota parlemen bila melanggar UU No. 7/2017 tentang pemilu. Baiknya regulasi pemilu bila tidak diikuti dengan moralitas serta kesadaran diri dari penyelenggara dan peserta serta pemilih, Pratik politik uang akan tetap ada, kesadaran serta ketaatan terhadap hukum adalah faktor utama nan penting.

2. Strategi dan upaya hukum guna menekan politik dapat dilakukan dengan tiga langkah, satu. Strategi melalui Legislasi, artinya memasukkan politik uang dalam kategori tindak pidana berat yang diikuti dengan pemberian sanksi dan hukuman yang berat pula. Hal ini penting dilakukan mengingat belum adanya hukum yang mengatur itu dan diantara kejahatan berat adalah kejatahan terorisme, narkoba dan tipikor. Hukuman maksimal bagi aktor politik uang dapat menimbulkan efek psikologis dan mencegah orang tersebut melakukan hal yang sama. Dua, Pencegahan melalui Yudikatif, efektivitas pengenaan hukum kasus politik uang dengan meningkatkan kerjasama penyelenggara pemilu dengan bekerja

\footnotetext{
${ }^{30}$ Undang-undang Nomor 7 Tahun 2017 Tentang Pemilu Pasal 280 Ayat (4)

31 Pasal 286 (1) UU Pemilu

32 Pasal 426 (1)

$33 \mathrm{Ibid}$,
}

180 HUKMY|Jurnal Hukum 
professional, efektif, menjunjung tinggi kejujuran dan mengasah SDM masingmasing penyelenggara dapat menyelamatkan demokrasi dari ancaman serius politik uang. Ketiga. Mencegah dengan Kebijakan Eksekusi dari peradilan, pengenaan eksekusi putusan bagi pelaku politik uang dengan meningkatkan fungsi pengawasan oleh lembaga berwenang. Upaya ini sebagai upaya guna memastikan putusan hukum yang dijatuhkan hakim terkait money politics dieksekusi dan dilaksanakan secara tepat dan benar serta berdasar.

\section{DAFTAR PUSTAKA}

Ahmad Khoirul Umam, Kiai dan Budaya Korupsi di Indonesia. Semarang: Rasail, 2006

Andi Akbar. Pengaruh Money Politics Terhadap Partisipasi Masyrakat Pada Pilkada 2015 Di Kabupaten Bulukumba ( studi kasus desa barugae kec. Bulukumpa) Program Studi Ilmu Politik Fakultas Ushuluddin, Filsafat Dan Ilmu Politik Universitas Islam Negeri (Uin) Alauddin Makassar

Bernard L. Tanya, Hukum, Politik, dan KKN, Surabaya: Srikandi, 2006

Dedi Irawan, "Studi Tentang Politik Uang (Money Politic) Dalam Pemilu Legislatif Tahun 2014: Studi Kasus Di Kelurahan Sempaja Selatan", Jurnal Ilmu Pemerintahan, Maret, 2015

Departemen Pendidikan Dan Kebudayaan, Kamus Besar Bahasa Indonesia, (Jakarta: Balai Pustaka, Edisi Kedua, 1994)

Heru Nugroho, Uang, Rentenir, dan Hutang Piutang di Jawa (Yogyakarta: Pustaka pelajar, 2001

Indah sri Utari. Pencegahan Politik Uang dan Penyelenggaraan Pilkada yang Berkualitas: Sebuah Revitalisasi Ideologi. Seminar Nasional Hukum Volume 2 Nomor 1 Tahun 2016, 451-474

M. Abdul Kholiq, 2014, "Perspektif Hukum Pidana tentang Fenomena Money Politics dan Korupsi Politk dalam Pemilu". Disampaikan pada Seminar Nasional Mewujudkan Pemilu yang Demokratis, Forum Kajian dan Penulisan Hukum (FKPH) Fakultas Hukum Universitas Islam Indonesia Yogjakarta Tanggal 22 maret 2014

Mahfud MD, Politik Hukum Di Indonesia, PT. Raja Grafindo. Jakarta. 2012

Muhammad Amanu. Politik Uang dalam Pemilihan Kepala Desa (Studi Kasus di Desa Jatirejo Kecamatan Banyakan Kabupaten Kediri) Jurnal Hukum Masyarakat Desa. Vol. 5. 2015 
Nanik Presetyoningsih, Jurnal Media Hukum, Dampak Pemilihan Umum Serentak Bagi Pembangunan Demokrasi Indonesia. Volume.21 Nomor 2 Desember Tahun 2014

Piege Johnson, "Partai Politik dan Konsolidasi Demokrasi di Indonesia", dalam Panduan Parlemen Indonesia, Jakarta: API, 2001

Roem Topatimasang, Menutup Pintu Masuk Politik Uang. Jakarta: Maarif Institute, 2011

Sumartini, Money Politics dalam Pemilu (Jakarta: Badan Kehakiman Hukum Nasional Departemen Kehakiman dan Hak Asasi Manusia, 2004)

Thahjo Kumolo, Politik Hukum PILKADA Serentak. Bandung, PT Mizan Publika, 2015

\section{Undang-Undang}

UUD NRI Tahun 1945

UU No. 7 Tahun 2017 Tentang Pemilihan Umum 